\title{
"Analytical Techniques for the Estimation of Pharmaceutical Drugs in Pure and Tablet Dosage Forms"
}

\author{
Pratik Paricharak*1 Ashpak Tamboli \\ Student \\ Associat Professor \\ Department of Pharmaceutical Chemistry
}

Sahyadri College of Pharmacy Methwade, Sangola 413307 , Solapur Maharashtra,India.

Corresponding auther : Pratik Paricharak . Email ID : paricharakp@gmail.com

Tel: 9172915891

\begin{abstract}
:
In this study, the author has developed a HPTLC method for the estimation of Chlorthalidone in Commercial brand CTD-12.5 of Chlorthalidone. The values obtained suggested that the proposed HPTLC method was simple , precise , rapid and robust for determination of Chlorthalidone. The mobile phase was simple to prepare and economical . The authors then validated the method as per ICH guidelines and correlated the obtained values with standard values. Satisfactory result were obtained .
\end{abstract}

KEYWORDS : Chlorthalidone, Validation of HPTLC, Method Development . INTRODUCTION :

Chlorthalidone having C14, H17, CIN2 , O4S . The Molar Mass of the Chlorthalidone is $338.766 \mathrm{~g} / \mathrm{mol}$. Chlorthalidone drug is Prescribed in the Treatment in High blood pressure ( Hypertension ), swelling including that due to heart, liver failure, and nephritic syndrome and diabetes insipidus and renal tubular acidosis . Common side effects include low blood potassium . Low blood sodium, high blood sugar .

Chlorthalidone was patented in 1975 and come into medical use in 1690 . It is available as generic medication . in 2017 it was the 173th most commonly 
prescribed medication in the united states, with more than three million prescription .

It is used in Medical use in High blood Pressure , Left ventricular hypertrophy , swelling, Bone fracture prevention, menieres disease, Diabetese insipidus .

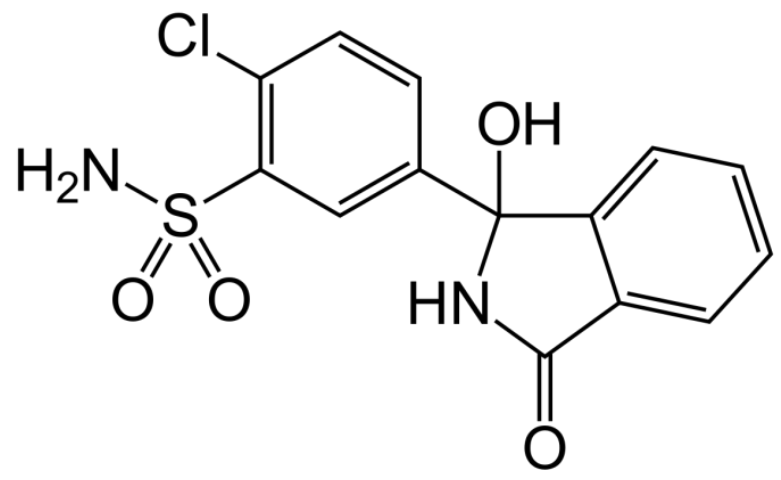

Fig no 1 : Structure of Chlorthalidone

\section{Material And Method :}

\subsection{Preparation of Standard stock Solution :}

Standard stock solution of drug prepared by dissolving $10 \mathrm{mg}$ of the drug in 10 $\mathrm{ml}$ of methanol to get concentration of $1000 \mathrm{mg} / \mathrm{ml}$. From the standard stock solution, working standard solution was prepared containing $500 \mathrm{mg} / \mathrm{ml}$ of Chlorthalidone .

\subsection{Selection of detection wavelength :}

From the Standard stock solution $(1000 \mathrm{mg} / \mathrm{ml})$ further dilutions were made using methanol and scanned over the range of 200-400 nm and the spectra was obtained . It was observed that the drug showed considerable absorbance at $275 \mathrm{~nm}$.

Respective UV spectrum of Chlorthalidone is Shown in fig no 2. 


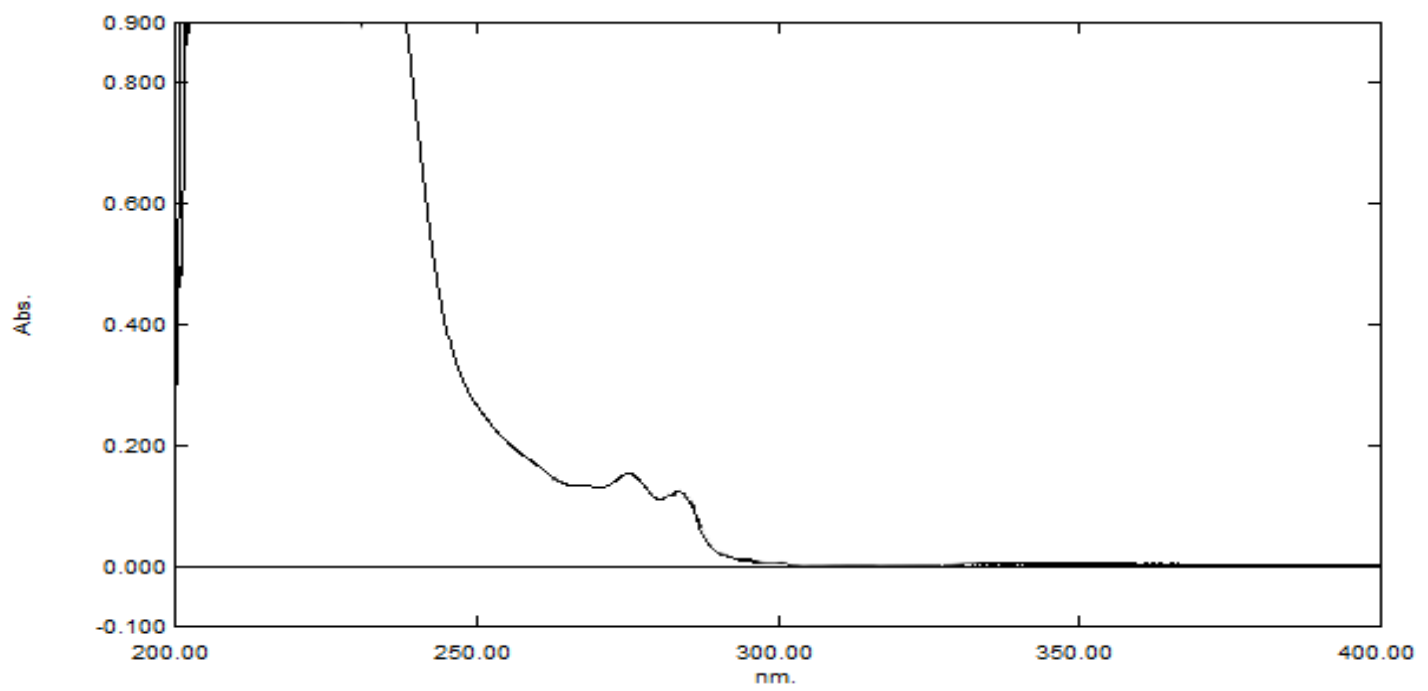

Fig 1 : The UV spectrum of Chlorthalidone $(10 \mathrm{mg} / \mathrm{ml})$

\subsection{Selection of Mobile phase and Chromatographic conditions :}

Chromatographic separation studies were carrid out on working standard of Chlorthalidone $1000 \mathrm{ng} /$ band . Initally, trials were carried out using solvants in various proportions on normal TLC plate to obtain the desired Rf And shape for drug peak. After few trials, Ethyl acetate : Methanol ( $7.5: 2.5 \mathrm{v} / \mathrm{v}$ ) was chosen as the mobile phase, Which gave acceptable peak parameter . Other chromatographic condition like chamber saturation time,run length ,Sample application volume were optimized.

\subsection{Preparation of Sample solution :}

For determination of the content of Chlorthalidone in Chlorthalidone tablets ( Lable clain:12.5mg Chlorthalidoneper tablet),twenty tablets werw weighed; average weight was determined and werw finely powdered.A quantity of powder equivalent to $10 \mathrm{mg}$ of Chlorthalidone was transferred to a $10 \mathrm{ml}$ volumetric flask containing $5 \mathrm{ml}$ of methanol. The mixture was ultra sonicated for $10 \mathrm{~min}$ and the resulting sample stock solution was filtered with Whatman filter paper no 41 and the volume was made up with the methanol. $5.0 \mathrm{ml}$ of this solution was diluted to $10 \mathrm{ml}$ with the methanol to prepare final stock solution of $500 \mathrm{mg} / \mathrm{ml}$. 


\subsection{Densitogramand system suitability parameter of drug :}

Solution of Chlorthalidone (500 mg/ml) was prepared. $2 \mathrm{ml}$ (1000 mg/band) of solution was applied on pre-activated TLC plate with the help of Hamilton syringe $(100 \mathrm{ml})$, using Linomat 5 sample applicator . The development chamber was saturatedwith mobile phase for $15 \mathrm{~min}$. The spotted plate was placed in saturated chamber and developed up to $80 \mathrm{~mm}$ distance. The plate was dried and was scanned over $90 \mathrm{~mm}$ distance at $275 \mathrm{~nm}$. The retention factor was found to be $0.43 \pm 0.07$. Representative densitogram of Chlorthalidone (1000 ng/band) is shown in fig.2

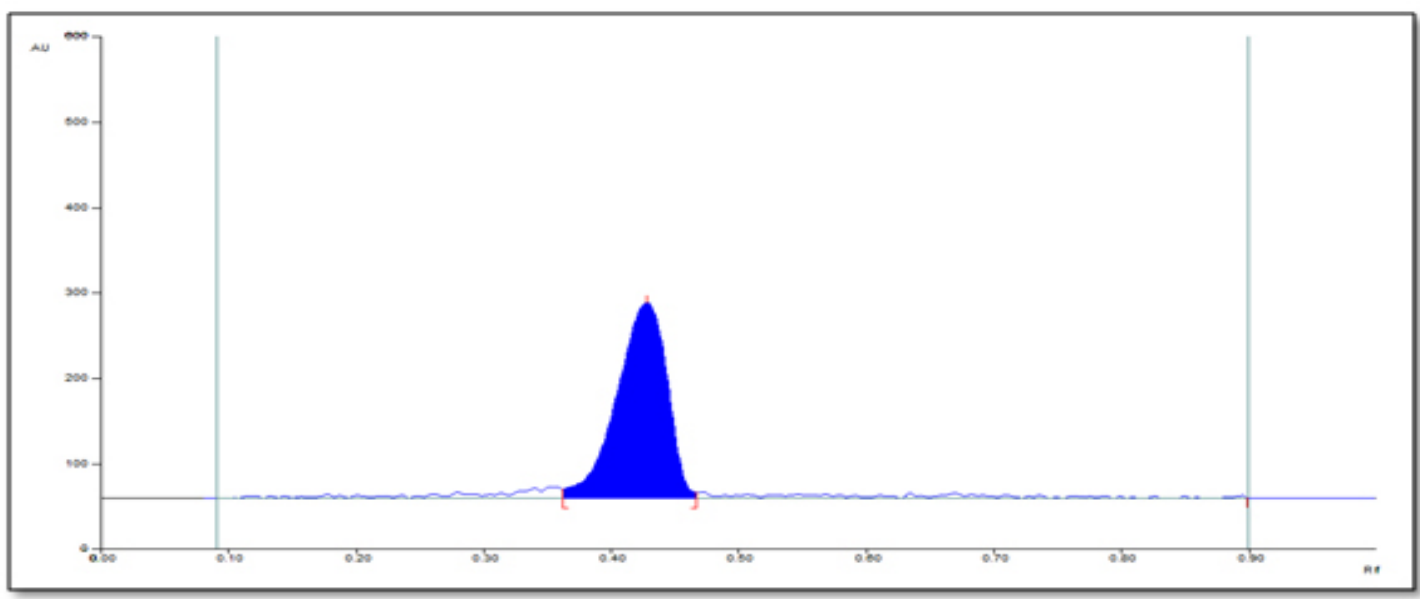

Fig 2 : Densitogram of standard solution of Chlorthalidone (1000 ng/band)

Table 2 : System suitability parameters for chlorthalidone :

\begin{tabular}{|l|l|l|l|l|}
\hline Drug & Conc. (ng/band) & Rf & Area & Asymmetry \\
\hline Chlorthalidone & 1000 & $0.43 \pm 0.07$ & 8447.7 & 0.86 \\
\hline
\end{tabular}




\subsection{Summary of chromatographic parameters selected :}

Chromatograpic parameter are summarized in Table 3

Table No 3 Chromatographic Parameters :

\begin{tabular}{|c|c|c|}
\hline Sr. No & Parameter & $\begin{array}{c}\text { Conditions used for } \\
\text { Analysis }\end{array}$ \\
\hline 1 & Stationary phase & $\begin{array}{c}\text { TLC aluminium plate } \\
\text { precoated with silica gel } 60 \\
\text { F254 }\end{array}$ \\
\hline 2 & Mobile phase & $\begin{array}{c}\text { Ethyl } \\
\text { acetate:MeOH(7.5:2.5v/v) }\end{array}$ \\
\hline 3 & Detection Wavelength & $275 \mathrm{~nm}$ \\
\hline 4 & Saturation time & $15 \mathrm{~min}$ \\
\hline 5 & Band width & $6 \mathrm{~mm}$ \\
\hline
\end{tabular}

\section{VALIDATION OF ANALYTICAL METHOD :}

\subsection{Specificity}

The specificity of the method was ascertained by peak purity profile studies. The peak purity values were found to be more than 0.998 , indicating the no interference of any other peak of degradation product , impurity or matrix.

\section{2 . Linearity :}

From the standard stock solution $(1000 \mathrm{mg} / \mathrm{ml})$ of Chlorthalidone, Solution was prepared containing $500 \mathrm{mg} / \mathrm{ml}$ of Chlorthalidone. This Solution was further used for spotting. Six replicates per concentration were spotted. The linearity (relationship between peak area and concentration) was determined by analyting six concentrations over the concentration range $500-3000 \mathrm{mg}$ / band to obtain calibration curve. The results found to br linear with regression equation $y=5.5173 x+2453.8$ and $R 2=0.9928$.

The result obtained are shown in Table 4. The calibration curve is shown in fig 3 . 
Table No 4 : Linearity study of Chlorthalidone :

\begin{tabular}{|c|c|c|c|c|c|c|}
\hline \multirow{2}{*}{\begin{tabular}{c}
\multirow{2}{*}{$\begin{array}{c}\text { Replic } \\
\text { ate }\end{array}$} \\
\cline { 2 - 7 }
\end{tabular}} & $\mathbf{5 0 0}$ & $\mathbf{1 0 0 0}$ & $\mathbf{1 5 0 0}$ & $\mathbf{2 0 0 0}$ & $\mathbf{2 5 0 0}$ & $\mathbf{3 0 0 0}$ \\
\cline { 2 - 7 } & \multicolumn{7}{|c|}{ Peak area } \\
\hline 1 & 4688.2 & 8447.7 & 10625.5 & 13595.5 & 16565.1 & 18059.5 \\
\hline 2 & 4611.6 & 8570.7 & 10503.3 & 13980.1 & 16551.3 & 18719.9 \\
\hline 3 & 4677.7 & 8596.6 & 10856.6 & 13513.9 & 16301.8 & 18865 \\
\hline 4 & 4681.5 & 8543.5 & 10575 & 13977.3 & 16231.4 & 18581.1 \\
\hline 5 & 4610.5 & 8572.8 & 10578.4 & 13469.7 & 16670.5 & 18564.5 \\
\hline 6 & 4694.4 & 8531.1 & 10547.3 & 13528.8 & 16552.6 & 18594.5 \\
\hline Avg & 4660.650 & 8543.733 & 10614.350 & 13677.550 & 16478.783 & 18564.077 \\
\hline SD & 38.844 & 52.439 & 125.282 & 236.740 & 171.718 & 272.268 \\
\hline$\%$ & 0.833 & 0.614 & 1.180 & 1.731 & 1.042 & 1.467 \\
\hline RSD & & & & & & \\
\hline
\end{tabular}

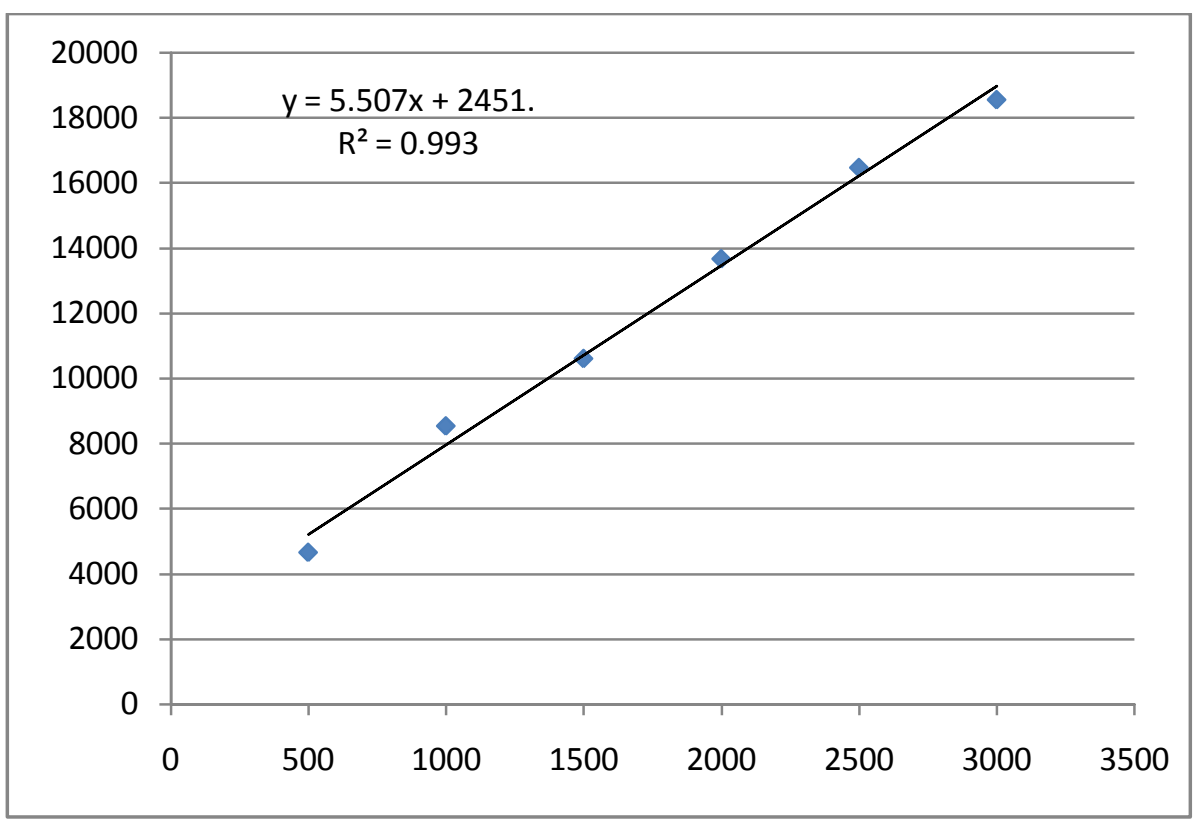

Fig 3 : Calibration curve of Chlorthalidone (500-3000 ng/band) reference standard 


\subsection{Range :}

Chlorthalidone $=500-3000 \mathrm{ng} / \mathrm{band}$

\section{4 : Precision :}

The precision of the method was demonstrated by intra-day and inter-day variation studies. In the intra-day studies 3 replicates of 3 concentrations were analysed on the same day, and \% RSD was calculated. For the interday variation studies, 3 concentrations were analysed on 3 consecutive days and \% RSD was calculated . For interaday precision and interday precision results obtained are shown in Table 5 and 6.

Table 5 : Intraday variation studies data for Chlorthalidone :

\begin{tabular}{|c|c|c|c|c|c|}
\hline Conc. (ng/band) & Area & $\begin{array}{c}\% \\
\text { recovery }\end{array}$ & Average & SD & \%RSD \\
\hline \multirow{3}{*}{1000} & 8072.8 & 102.079 & \multirow{3}{*}{101.422} & \multirow{3}{*}{0.614} & \multirow{3}{*}{0.605} \\
\hline & 8031.1 & 101.322 & & & \\
\hline & 8005.9 & 100.864 & & & \\
\hline \multirow{3}{*}{1500} & 10578.4 & 98.385 & \multirow{3}{*}{98.734} & \multirow{3}{*}{0.513} & \multirow{3}{*}{0.520} \\
\hline & 10587.3 & 98.493 & & & \\
\hline & 10655.9 & 99.323 & & & \\
\hline \multirow{3}{*}{2000} & 13528.8 & 100.576 & \multirow{3}{*}{101.343} & \multirow{3}{*}{0.669} & \multirow{3}{*}{0.660} \\
\hline & 13646.8 & 101.648 & & & \\
\hline & 13664.2 & 101.806 & & & \\
\hline
\end{tabular}


Table 6 : Interday variation studies data for Chlorthalidone :

\begin{tabular}{|c|c|c|c|c|c|}
\hline Conc. (ng/band) & Area & $\begin{array}{c}\% \\
\text { recovery }\end{array}$ & Average & SD & \%RSD \\
\hline \multirow{3}{*}{1000} & 1010.785 & 101.078 & \multirow{3}{*}{101.114} & \multirow{3}{*}{0.170} & \multirow{3}{*}{0.168} \\
\hline & 1012.982 & 101.298 & & & \\
\hline & 1009.641 & 100.964 & & & \\
\hline \multirow{3}{*}{1500} & 1484.327 & 98.955 & \multirow{3}{*}{99.375} & \multirow{3}{*}{1.254} & \multirow{3}{*}{1.261} \\
\hline & 1511.765 & 100.784 & & & \\
\hline & 1475.775 & 98.385 & & & \\
\hline \multirow{3}{*}{2000} & 2023.641 & 101.182 & \multirow{3}{*}{100.733} & \multirow{3}{*}{0.395} & \multirow{3}{*}{0.392} \\
\hline & 2008.823 & 100.441 & & & \\
\hline & 2011.529 & 100.576 & & & \\
\hline
\end{tabular}

\subsection{Limit of Detection (LOD) and Limit of quantitation (LOQ)}

LOD and LOQ are calculated from the formula :

$$
\operatorname{LOD}=\frac{3.3 \sigma}{\mathrm{s}} \quad \mathrm{LOQ}=\frac{10 \sigma}{\mathrm{S}}
$$

Where,

$\sigma=$ Standard deviation of $Y$ intercept;

$\mathrm{S}=$ Average of slope of the calibration curve 


\section{Table 7 : LOD and LOQ of Chlorthalidone}

\begin{tabular}{|c|c|c|c|c|}
\hline Method & Avg slope & S.D & LOQ (ng/band) & LOD(ng/band) \\
\hline Using S.D of y-intercept & 5.523 & 94.028 & 170.24 & 56.18 \\
\hline
\end{tabular}

\subsection{Assay:}

Chlorthalidone 12.5 mgtablet (Niksan Healthcare) formulation analysis was carried out as mentioned under section preparation of sample solution. Procedure was repeated for six times. $2 \mu \mathrm{l}$ volume of sample solution was applied and area was recorded. Basic concentration of sample chosen was 1000 ng/band from tablet solution. Concentration and \% recovery was determined from linear equation. Assay results obtained are shown in Table 8. 


\section{Table 8: Assay of marketed formulation}

\begin{tabular}{|c|c|c|c|}
\hline Sr. No. & Peak area & $\begin{array}{c}\text { Amount recovered } \\
\text { (ng/band) }\end{array}$ & \% recovery \\
\hline 1 & 7999.8 & 1007.534 & 100.753 \\
\hline 2 & 7947.6 & 998.055 & 100.815 \\
\hline 3 & 8003.2 & 1008.152 & 100.644 \\
\hline 4 & 7993.8 & 1006.445 & 100.456 \\
\hline 5 & 7983.4 & 1004.556 & 100.770 \\
\hline 6 & 8000.7 & 1007.698 & 100.541 \\
\hline Mean & 7988.083 & 1005.407 & 0.382 \\
\hline SD & 21.064 & 3.825 & 0.380 \\
\hline \%RD & 0.264 & 0.380 & \\
\hline
\end{tabular}

\subsection{Accuracy:}

To check accuracy of the method, recovery studies were carried out by spiking the standard drug to the tablet solution, at three different levels 50, 100 and 150\%. Basic concentration of sample chosen was 1000 ng/band. \% recovery was determined from linear equation. Accuracy results obtained are shown in Table 9 
Table 9: Accuracy studies of Chlorthalidone

\begin{tabular}{|c|c|c|c|c|c|}
\hline Level & $\begin{array}{c}\text { Amount of } \\
\text { sample } \\
\text { taken } \\
\text { (ng/band) }\end{array}$ & $\begin{array}{c}\text { Amount of } \\
\text { standard } \\
\text { spiked } \\
\text { (ng/band) }\end{array}$ & Area & $\begin{array}{l}\text { Amount } \\
\text { recovered } \\
\text { (ng/band) }\end{array}$ & $\begin{array}{c}\text { \% recovery } \\
\text { (Mean } \\
\pm \% \text { RSD) }\end{array}$ \\
\hline \multirow{3}{*}{$50 \%$} & \multirow{3}{*}{1000} & \multirow{3}{*}{500} & 10784.6 & 1513.218 & \multirow{3}{*}{$\begin{array}{l}100.390 \\
\pm 0.446\end{array}$} \\
\hline & & & 10735.2 & 1504.248 & \\
\hline & & & 10712.2 & 1500.071 & \\
\hline \multirow{3}{*}{$100 \%$} & \multirow{3}{*}{1000} & \multirow{3}{*}{1000} & 13648.2 & 2033.211 & \multirow{3}{*}{$\begin{array}{l}100.992 \\
\pm 1.227\end{array}$} \\
\hline & & & 13658.5 & 2035.081 & \\
\hline & & & 13417.1 & 1991.246 & \\
\hline \multirow{3}{*}{$150 \%$} & \multirow{3}{*}{1000} & \multirow{3}{*}{1500} & 16199.5 & 2496.494 & \multirow{3}{*}{$\begin{array}{l}100.564 \\
\pm 0.882\end{array}$} \\
\hline & & & 16433.6 & 2539.003 & \\
\hline & & & 16256.4 & 2506.826 & \\
\hline
\end{tabular}

\subsection{Robustness :}

Robustness of the method was determined by carrying out the analysis under conditions during which chamber saturation time was altered. Time was also changed from spotting to development and development to scanning and the effects on the area were noted. It was found that method is robust. The results obtained are shown in Table10 


\section{Table 10: Robustness study}

\begin{tabular}{|c|c|c|c|}
\hline $\begin{array}{l}\text { Sr. } \\
\text { No. }\end{array}$ & Parameters & Variation & \%RSD \\
\hline \multirow{3}{*}{1.} & \multirow{3}{*}{$\begin{array}{c}\text { Time from application } \\
\text { to development }\end{array}$} & $0 \mathrm{~min}$ & 1.465 \\
\hline & & $30 \mathrm{~min}$ & 1.111 \\
\hline & & $60 \mathrm{~min}$ & 0.759 \\
\hline \multirow{3}{*}{2.} & \multirow{3}{*}{$\begin{array}{l}\text { Time from } \\
\text { development to } \\
\text { scanning }\end{array}$} & $0 \mathrm{~min}$ & 1.477 \\
\hline & & $30 \mathrm{~min}$ & 1.464 \\
\hline & & $60 \mathrm{~min}$ & 0.879 \\
\hline \multirow{3}{*}{3.} & \multirow{3}{*}{ Saturation Time } & $15 \mathrm{~min}$ & 0.614 \\
\hline & & $13 \mathrm{~min}$ & 0.942 \\
\hline & & $17 \mathrm{~min}$ & 0.858 \\
\hline
\end{tabular}




\section{Summary of validation study}

Table 11: Summary of Validation Parameters

\begin{tabular}{|c|c|c|}
\hline Sr. No. & Validation parameters & Chlorthalidone \\
\hline \multirow{3}{*}{1.} & Linearity equation & $y=5.507 x+2451.309$ \\
\hline & $\mathrm{R}^{2}$ & $\mathrm{R}^{2}=0.993$ \\
\hline & Range & 500-3000ng/band \\
\hline \multirow{3}{*}{2.} & Precision & (\%RSD) \\
\hline & Intraday & 1.417 \\
\hline & Interday & 1.028 \\
\hline 3. & Assay & $100.541 \pm 0.380$ \\
\hline \multirow{4}{*}{4.} & Accuracy & \\
\hline & 50 & $100.390 \pm 0.446$ \\
\hline & 100 & $100.992 \pm 1.227$ \\
\hline & 150 & $100.564 \pm 0.882$ \\
\hline 5. & Limit of detection & 56.18ng/band \\
\hline 6. & Limit of quantitation & 170.24ng/band \\
\hline 7. & Specificity & Specific \\
\hline 8. & Robustness & Robust \\
\hline
\end{tabular}

\section{Conclusion :}

It includes that the developed method is simple , accurate and precise and suitable for the routine analsis, The developed method werw validated as per ICH guidelines and were found to be within limit. 


\section{Acknowledgement :}

I am thankful to Sahyadri college of Pharmacy,Methwade ( Sangola ), Maharashtra. For giving permission to carry out my work .

\section{Reference :}

1. Singh B, Patel DK, Ghosh SK. A Reversed phase high performance liquid chromatographic method for determination of chlorthalidone in pharmaceutical formulation. Int J Pharm Pharm Sci 2009;1(2):24-9.

2. Validation of analytical procedures, ICH Hormonised Tripartite Guidelines, Q2B; 1997.

3. Sweetman SC. Martindale, The complete drug reference. $36^{\text {th }}$ ed. Pharmaceutical press: London; 2009;975:3.

4. http://en.wikipedia.org/wiki/Chlortalidone

5. Singh, B;Patel, DK andGhosh, SK (2009), “A Reversed-Phase High Performance Liquid Chromatographic Method For Determination Of Chlorthalidone In Pharmaceutical Formulation,’Int. J. Pharm. Pharmceut. Sci,Vol 1, 24-29.

6. Jayprakash R , Kommi R , Gandhi K.R , Indo Americal Journal of Pharmaceutical research 2014(4);3654-3661.

7. Budavari S . The Merck Index. $14^{\text {th }}$ ed Merck and Co.Inc Whitehouse station NJ:Merck;2006.p.22.

8. Christopher M Riley, Thomas W. Rosaznske, Develepment and Validation of Analytical Methos. 3 Pergamon 1996.3-167.

9. Vartak PJ and Shikha MN: Analytical Chemistry, An Indian Journal 2015; 15(3): 111-16.

10. Reynolds J: Martindale: The Extra Pharmacopoeia, A publication of Pharmaceutical Press, Sixth Edition, UK; 1: 1214-20. 